\title{
Title: Risk Perception related to COVID-19 among Sub-Sahara Africans: A Web-based Comparative Survey of local and diaspora residents
}

\section{Emmanuel Kwasi Abu}

University of Cape Coast

Richard Oloruntoba

Curtin University

Uchechukwu Levi Osuagwu ( $\square$ l.osuagwu@westernsydney.edu.au )

Western Sydney University

Dipesh Bhattarai

Deakin University

Chundung Asabe Miner

University of Jos

Piwuna Christopher Goson

University of Jos

\section{Raymond Langsi}

University of Bamenda

Obinna Nwaeze

County Durham and Darlington NHS Foundation Trust

Timothy G Chikasirimobi

Masinde Muliro University of Science and Technology

Godwin O Ovenseri-Ogbomo

Qassim University

\section{Bernadine N Ekpenyong}

University of Calabar

Deborah Donald Charwe

Tanzania Food and Nutrition Center

Khathutshelo Percy Mashige

University of KwaZulu-Natal

Tanko Ishaya

University of Jos

Kingsley Emwinyore Agho

Western Sydney University 


\section{Research Article}

Keywords: Africa, pandemic, diaspora, lockdown, risk perception, Sub-Sahara Africa, knowledge, COVID19

Posted Date: March 3rd, 2021

DOI: https://doi.org/10.21203/rs.3.rs-258151/v1

License: (c) (i) This work is licensed under a Creative Commons Attribution 4.0 International License. Read Full License

Version of Record: A version of this preprint was published at BMC Public Health on August 18th, 2021. See the published version at https://doi.org/10.1186/s12889-021-11600-3. 


\section{Abstract \\ Background}

Perceived risk towards the coronavirus pandemic is a key to improved compliance with public health measures to reduce the infection. This study investigated how Sub-Saharan Africans (SSA) living in their respective countries and those in the diaspora perceive their risk of COVID-19 outbreak and the factors associated.

\section{Methods}

A web-based cross-sectional survey on 1969 participants aged 18 years and above ( $55.1 \%$ male) was conducted between April 27th and May 17th 2020.

The dependent variable was perception of risk for contracting COVID-19 scores. Independent variables included demographic characteristics; COVID-19 related knowledge and attitude scores. Univariate and multiple linear regression analyses identified the factors associated with risk perception towards COVID19.

\section{Results}

Among SSA respondents, majority were living in SSA $(n=1855,92.8 \%)$ and $143(7.2 \%)$ in the diaspora. There was no significant difference in the mean risk perception scores between the two groups $(p=$ $0.117)$, however, those aged 18-28 years had lower risk perception scores $(p=0.003)$ than the older respondents, while those who were employed $(p=0.040)$ and had higher level of education $(p<0.001)$ had significantly higher risk perception scores than other respondents. After adjusting for covariates, multivariable analyses revealed that SSA residents aged 39-48 years (adjusted coefficient, $\beta=0.06,95 \%$ $\mathrm{Cl}[0.01,1.19])$ and health care sector workers $(\beta=0.61,95 \% \mathrm{Cl}[0.09,1.14])$ reported a higher perceived risk of COVID-19. Knowledge and attitude scores increased as perceived risk for COVID-19 increases for both SSAs in Africa ( $\beta=1.19,95 \% \mathrm{Cl}[1.05,1.34]$ for knowledge; $\beta=0.63,95 \% \mathrm{Cl}[0.58,0.69]$ for attitude) and in Diaspora $(\beta=1.97,95 \% \mathrm{Cl}[1.16,2.41]$ for knowledge; $\beta=0.30,95 \% \mathrm{Cl}[0.02,0.58]$ for attitude).

\section{Conclusions}

There is a need to promote preventive measures with focus on increasing people's knowledge about COVID-19 and encouraging positive attitude towards the mitigation measures.

Such interventions should target older participants and non-healthcare workers.

\section{Introduction}


Risk perception refers to people's subjective assessments of the possibility of outcomes that may follow undesirable events such as disasters and pandemics[1]. Assessment of risk perception is important in health and risk communication as it relates to individuals understanding of risks, their feelings and how they deal with those risks. The ongoing novel coronavirus SARS-CoV2 (COVID-19) pandemic has caused enormous global mortality and public health devastation[2], while renewing our collective awareness of global pandemics[3]. The 2014 West African Ebola Virus Disease (EVD) pandemic was limited to African countries, and severe acute respiratory syndrome (SARS) of 2002-03 limited to Asian countries, COVID19 has been a global and unprecedented 'black swan' event[4, 5]. COVID-19 infection is highly contagious and mortality caused by the virus has exceeded 2.4 million deaths as at 15th of February 2021 - more than any of its predecessors[6]. It is therefore no surprise that, countries are in a race towards developing an effective vaccine[7, 8].

The COVID-19 virus poses a considerable global threat[9], hence, the World Health Organization (WHO) immediately raised awareness of healthcare workers around the world[10]. The WHO has also raised funds globally and developed Strategic Preparedness and Response Plans (SPRP) to support and protect poorer countries with weak healthcare systems[11]. The goal of the SPRP was to control infection, limit transmission, communicate key information, provide early acute care, and minimize disastrous economic and social effects. National governments locked-down their populations, stopped the mobility of goods and services and closed all schools and universities as well as state and international borders with many employees working from home [12-15]. Nonetheless, the success of these mitigating measures is dependent upon the public's readiness to comply, which in turn is inspired by their risk perceptions about the pandemic[16]. According to the extended parallel process model (EPPM) of health communication, the two cognitive assessments that may ensue after a person's exposure to a health risk are related to the perceived threat it poses and the perceived efficacy of the recommended advice[17]. This is critical to behavioral changes.

Globally, devastating pandemics such as COVID-19 can provide valuable opportunities to learn about human risk perception and attendant behavior $[18,19]$ and how findings from such studies can be used to inform allocation of resources within such countries, and within international multilateral organizations and agencies such as the $\mathrm{WHO}[20,21]$. Such studies can also provide an evidence base for formulation of (public) health and risk policy. Severe outcomes from natural disasters are often influenced by the level and distribution of economic resources and income within the population of a country (or region) $[22,23]$ and well-resourced quality institutions[24]. Several seminal bodies of literature highlight the role of resources or the lack of it in societal responses to disasters[25] and show how positive psychology can contribute to community development during disasters[26].

Risk perception lead to decision-making and adjustment to the risks in a number of ways: they can move out of harm by self-isolation; they can self-protect; or they can prepare in various ways for a disaster, or ignore public warnings[27]. Quinn et al showed that people's attachment to their place of residence has an effect on how people perceive disaster related risk[28]. Hence, risk perception influences how individuals behave and respond to recommended health behaviours [29]. There are limitations to surveys 
such as this to assess risk perceptions and compare the perceptions from sub-Sahara African (SSA) residents in and outside Africa. Ideally, one would like to be able to hold political institutions and the cultural context constant to be able to make comparisons. The findings of this study will highlight the implications of the analysis for what we might expect for Africans living in Africa and in the diaspora (living outside Africa) and policy implications in disaster risk management in general. For policy makers tasked with communicating risk, this research can provide a particularly fruitful lens in addressing the emotional underpinnings of adaptation behaviour.

\section{Methods}

\section{Design and Setting of the study}

This was an online survey created in Survey monkey to assess risk perceptions of Africans. The study was conducted between April 27th and May 17th 2020 corresponding to the mandatory lockdown period in most SSA countries. The survey instrument was adapted and developed from the WHO recommended questions [30] and have been used in previous studies[30]. At this special period of lockdown and restricted mobility, it was not feasible to undertake a conventional Africa-wide community-based sampling survey. A one-page project information statement, which doubled as a recruitment poster, was posted/reposted to WhatsApp and Facebook chat groups and individual accounts together with an e-Link to the online survey. The information sheet and poster contained a brief introduction on the background of the study, its objectives, procedures, the voluntary nature of participation, the declaration of anonymity, privacy and confidentiality as well as instructions for completing the questionnaire.

We also posted the poster and questionnaire on various websites and official accounts of several local organisations and individuals.

Survey questionnaires were also sent out by email to selected groups and individuals in all the target countries relying on the authors' networks with collaborating academics and local people.

\section{Questionnaire}

The questionnaire was divided into three sections, including demographics, knowledge, risk perception, feeling about self-isolation, attitude towards public health practices to mitigate the spread of COVID-19 (compliance) as presented in Table 1. Most of the items on the questionnaire that assessed the respondent's knowledge of COVID-19, required mostly a 'true' or 'false' or a 'yes' or 'no' response with an additional "I don't know" option. Each question used a binary scale and a correct answer was assigned 1 point whereas an incorrect/unknown answer was assigned 0 point. The knowledge score ranged from 019 points. These items have been validated elsewhere to have an acceptable internal consistency[31].

For the risk perception items shown in P1 - P6 of Table 1, each question used a Likert scale with five levels and the scores ranged from 1 for 'lowest' and 5 for 'highest' with a maximum score range of 5 to 30 points. We determined the Cronbach's alpha coefficients of the perception items to be 0.84 , which indicated a satisfactory internal consistency of perception items. Questions were asked on "How the 
respondents felt about self-isolation" (P7 - P12) with responses utilizing a Likert scale with five levels and the scores also ranged from 1 (lowest) to 5 (highest). The Cronbach's alpha coefficient of the "How the respondents felt about the quarantine items" was 0.74 , which indicated an acceptable internal consistency. Respondents were also asked about their attitude towards the public health measures put in place by the respective governments to reduce the spread of the virus in items A1-A8.

\section{Characteristics of the participants}

Participants were those living in South Africa, Nigeria, Ghana, Kenya, Tanzania and Malawi.

Respondents in the diaspora including those living in the UK, USA, Australia, Canada, New Zealand and Germany were also included. Recipients were further encouraged to send on or 'snowball' the survey questionnaire to other WhatsApp groups that they know as well as to friends. Eligibility criteria included that respondents had to be of African nationality, aged 18 years or older and able to understand the contents of the poster/questionnaire, and agreed to participate in the study. 
Table 1

Survey items for knowledge, attitude and perception towards COVID-19.

\section{Knowledge}

K1 Are you aware of the Coronavirus disease (COVID-19) outbreak?

K2 Are you aware of the origin of the Coronavirus disease (COVID-19) outbreak?

K3 Do you think Coronavirus disease (COVID-19) outbreak is dangerous?

K5 Do you think Hand Hygiene / Hand cleaning is important to control the spread of the Coronavirus disease (COVID-19) outbreak?

K6 Do you think ordinary residents can wear general medical masks to prevent the infection by the COVID-19 virus?

K7 Do you think there are any specific medicines to treat Coronavirus disease (COVID-19)?

K8 The main clinical symptoms of Coronavirus disease (COVID-19) are:

Fever, Fatigue, dry cough, sore throat

K9 Unlike the common cold, stuffy nose, runny nose, and sneezing are less common in persons infected with the COVID-19 virus.

K10 There currently is no effective cure for COVID-2019, but early symptomatic and supportive treatment can help most patients recover from the infection

K11 It is not necessary for children and young adults to take measures to prevent the infection by the COVID-19 virus

K12 COVID-19 individuals cannot spread the virus to anyone if there's no fever

K13 The COVID-19 virus spreads via respiratory droplets of infected individuals

K14 To prevent getting infected by Coronavirus disease (COVID-19), individuals should avoid going to crowded places such as train stations, religious gatherings, and avoid taking public transportation

K15 Isolation and treatment of people who are infected with the Coronavirus disease (COVID-19) virus are effective ways to reduce the spread of the virus. The observation period is usually 14 days

K16 Not all persons with COVID-2019 will develop to severe cases. Only those who are elderly, have chronic illnesses, and are obese are more likely to be severe cases.

\section{Risk Perception}

Please rate your chances of personal risk of infection with COVID-19 for each of the following?

P1 Risk of becoming infected.

P2 Risk of becoming severely infected

P3 Risk of dying from the infection

P4 How much worried are you because of COVID-19? 


\section{Knowledge}

P5 How likely do you think Coronavirus disease (COVID-19) will continue in your country?

P6 If Coronavirus disease (COVID-19) continues in your country, how concerned would you be that you or your family would be directly affected?

How do you feel about the Self-isolation?

P7 I am worried about self-isolation.

P8 I am bored by self-isolation.

P9 I am frustrated by self-isolation

P10 I am angry because of self-isolation.

P11 I am anxious about self-isolation.

P12 I am angry because of quarantine.

\section{Attitude towards public health practices to mitigate the spread of COVID-19 (Compliance)}

A1 Are you currently or have you been in (domestic/home) quarantine because of COVID-19?

A2 Are you currently or have you been in self-isolation because of COVID-19?

A3 In recent days, have you gone to any crowded place including religious events?

A4 In recent days, have you worn a mask when leaving home?

A5 In recent days, have you been washing your hands with soap and running water for at least 20 seconds each time?

A6 Since the government gave the directives on preventing getting infected, have you procured your mask and possibly sanitizer?

A7 Have you travelled outside your home in recent days using the public transport

A8 Are you encouraging others that you meet to observe the basic prevention strategies suggested by the authorities?

\section{Dependent variable}

The dependent variable for this study was perception of risk for contracting COVID-19, which was categorized as continuous. The items utilized to measure risk perception of COVID-19 are shown in Table 1 (P1-P6). The response included very high, high, low, very low, and unlikely.

\section{Independent variables}

These included demographic A) characteristics of the participants which consists of age, gender, marital status, education, employment status, occupation (if employed), religion, if they lived alone, number of people living together in the household and place of current residence. 
B), Knowledge about COVID-19 origin, symptoms and prevention. C), Feeling about the practice of selfisolation during COVID-19 lockdown. D) Attitude towards COVID-19 mitigation measures that included practice of self-isolation, home quarantine (A1 and A2) as well as compliance questions (A3-A8)(see Table 1).

\section{Sample size determination}

The survey assumed a proportion of $50 \%$ with $95 \%$ confidence and $2.5 \%$ margin of error. This is because the main objective of this research was on COVID-19, and there are no previous studies from SSA that examined factors associated with risk perception of 2019-nCoV. An online sample size calculator was used, and we assumed a sample size of approximately 1921, including $20 \%$ non-response rate.

\section{Statistical analysis}

Scores for risk perception were calculated for each of the independent variables and treated as continuous variable with mean ( \pm standard deviation) risk scores. The risk scores ranged from 1 to 30 . Risk scores by independent variables were summarized using t-test for two categorical groups and oneway analysis of variance (ANOVA) for more than two categorical groups. Univariate linear regression analyses were conducted to assess the unadjusted coefficients (B) with $95 \%$ confidence intervals among SSA residents and residents in the diaspora. The adjusted coefficients $(\beta)$ with $95 \%$ confidence intervals obtained from the multiple linear regression model were used to measure the factors associated with risk perception of COVID-19 among SSA residents and those in the diaspora. Only significant variables in the univariate analysis were used to build the regression model. Knowledge was included in the model because it is strongly related to attitude and practice while knowledge and attitude has been reported to be associated with practice ${ }^{([32])}$. Feeling about the practice of self-isolation during COVID-19 lockdown would help in identifying individuals who could develop mental health issue during the lockdown. Including attitude towards the mitigation practices in the model would influence action to reduce the spread of the infection. All analysis were performed using Stata version 14.1 (Stata Corp. College Station United States of America) and a two-tailed $p$-value $<0.05$ was considered statistically significant.

\section{Results}

\section{Demographics of respondents in Africa and in the diaspora}

Of 1,969 respondents ( $55.1 \%$ male and $44.9 \%$ female) that completed the survey, majority were living in SSA $(n=1855,92.8 \%)$ and $143(7.2 \%)$ in the diaspora at the time of data collection. Figure 1 presents the mean and the $95 \% \mathrm{Cl}$ of risk perception scores towards COVID-19 based on respondents region of residence. There was no significant difference in the mean risk perception scores between the two groups $(p=0.117)$. Table 2 shows the demographics of SSA in Africa and in the diaspora with their mean (standard deviation) scores for perceived risk towards COVID-19. Compared to SSA residents, those living in the diaspora were younger, more often female, and less often married.

\section{Perception of overall COVID-19-associated risk}


For those in SSA, the risk perception score was significantly lower in the 18-28 years age group ( $p=$ 0.003 , Table 2$)$ than in older age groups. Again, employment $(p=0.040)$ and higher level of education ( $p$ $<0.001$, Table 2) had significantly higher risk perception scores than being unemployed with lower education, respectively. There was no significant difference in the risk perception scores based on gender, marital status, religion, occupation, and the number of people living together, among SSA residents. The risk perception score did not yield any significant difference on sociodemographic characteristics among participants living in the diaspora. 
Table 2

Demographics of Sub-Saharan Africans living in Africa and in the diaspora with their mean (standard deviation) scores for perceived risk of contracting COVID-19.

\begin{tabular}{|c|c|c|c|c|c|c|}
\hline Variables & $\begin{array}{l}\text { Local } \\
\text { SSA }\end{array}$ & \multicolumn{2}{|c|}{ Scores $P$-value } & $\begin{array}{l}\text { Diaspora } \\
\text { SSA }\end{array}$ & Scores & $\begin{array}{l}P \\
\text { value }\end{array}$ \\
\hline \multicolumn{7}{|l|}{ Demography } \\
\hline \multicolumn{7}{|l|}{ Age category in years, $n=1818(\dagger)$} \\
\hline $18-28$ & 722 & $\begin{array}{l}20.0 \\
(8.1)\end{array}$ & 0.003 & 52 & $\begin{array}{l}20.7 \\
(8.1)\end{array}$ & 0.371 \\
\hline $29-38$ & 476 & 21.3(7.3) & & 47 & $\begin{array}{l}20.2 \\
(7.5)\end{array}$ & \\
\hline $39-48$ & 393 & 21.3(7.7) & & 31 & $\begin{array}{l}18.3 \\
(8.9)\end{array}$ & \\
\hline $49+$ & 227 & 21.6(7.1) & & 13 & $\begin{array}{l}22.5 \\
(5.6)\end{array}$ & \\
\hline \multicolumn{7}{|l|}{ Sex, $n=1822$} \\
\hline Males & 1002 & $\begin{array}{l}21.0 \\
(7.6)\end{array}$ & 0.394 & 80 & $\begin{array}{l}21.0 \\
(7.0)\end{array}$ & 0.118 \\
\hline Females & 820 & $\begin{array}{l}20.7 \\
(7.9)\end{array}$ & & 62 & $\begin{array}{l}18.9 \\
(8.8)\end{array}$ & \\
\hline \multicolumn{7}{|l|}{ Marital status, $n=1825$} \\
\hline Married & 793 & $\begin{array}{l}21.1 \\
(7.4)\end{array}$ & 0.293 & 70 & $\begin{array}{l}20.1 \\
(8.2)\end{array}$ & 0.929 \\
\hline Not married $\square$ & 1032 & $\begin{array}{l}20.7 \\
(8.0)\end{array}$ & & 73 & $\begin{array}{l}20.2 \\
(7.7)\end{array}$ & \\
\hline \multicolumn{7}{|l|}{ Education status, $n=1827(\dagger)$} \\
\hline $\begin{array}{l}\text { Postgraduate education (Masters } \\
\text { /PhD) }\end{array}$ & 576 & $21.3(6.8)$ & $\dot{0} 001$ & 56 & $\begin{array}{l}20.4 \\
(7.7)\end{array}$ & 0.918 \\
\hline Bachelor education & 861 & $\begin{array}{l}21.1 \\
(7.8)\end{array}$ & & 64 & $\begin{array}{l}20.1 \\
(8.2)\end{array}$ & \\
\hline Secondary/Primary education & 390 & $\begin{array}{l}19.1 \\
(9.0)\end{array}$ & & 23 & $\begin{array}{l}19.5 \\
(7.2)\end{array}$ & \\
\hline \multicolumn{7}{|l|}{ Employment status, $\mathrm{n}=1830$} \\
\hline Employed & 1200 & $\begin{array}{l}21.1 \\
(7.5)\end{array}$ & 0.040 & 97 & $\begin{array}{l}19.8 \\
(7.7)\end{array}$ & 0.462 \\
\hline Not employed & 630 & $\begin{array}{l}20.3 \\
(8.2)\end{array}$ & & 46 & $\begin{array}{l}20.9 \\
(8.3)\end{array}$ & \\
\hline
\end{tabular}




\begin{tabular}{|c|c|c|c|c|c|c|}
\hline Variables & $\begin{array}{l}\text { Local } \\
\text { SSA }\end{array}$ & \multicolumn{2}{|c|}{ Scores $P$-value } & $\begin{array}{l}\text { Diaspora } \\
\text { SSA }\end{array}$ & Scores & $\begin{array}{l}P \\
\text { value }\end{array}$ \\
\hline \multicolumn{7}{|l|}{ Religion, $n=1825$} \\
\hline Christianity & 1605 & $\begin{array}{l}20.8 \\
(7.7)\end{array}$ & 0.510 & 136 & $\begin{array}{l}20.2 \\
(7.8)\end{array}$ & 0.802 \\
\hline Others & 220 & $\begin{array}{l}21.2 \\
(7.6)\end{array}$ & & 7 & $\begin{array}{l}19.4 \\
(9.6)\end{array}$ & \\
\hline \multicolumn{7}{|l|}{ Occupation, 1753} \\
\hline Non-health care sector & 1357 & $\begin{array}{l}20.6 \\
(7.8)\end{array}$ & 0.109 & 111 & $\begin{array}{l}19.6 \\
(8.1)\end{array}$ & 0.743 \\
\hline Health care sector & 396 & $21.3(7.8)$ & & 34 & $\begin{array}{l}20.2 \\
(8.9)\end{array}$ & \\
\hline \multicolumn{7}{|l|}{ House hold factors } \\
\hline \multicolumn{7}{|c|}{$\begin{array}{l}\text { Do you live alone during COVID-19, } \\
\mathrm{n}=1826\end{array}$} \\
\hline No & 1483 & $\begin{array}{l}20.8 \\
(7.6)\end{array}$ & 0.864 & 117 & $\begin{array}{l}20.0 \\
(7.8)\end{array}$ & 0.860 \\
\hline Yes & 343 & $\begin{array}{l}20.9 \\
(8.1)\end{array}$ & & 26 & $\begin{array}{l}20.3 \\
(8.6)\end{array}$ & \\
\hline \multicolumn{7}{|c|}{$\begin{array}{l}\text { Number living together, } n=1650 \\
(t)\end{array}$} \\
\hline 1-3 people & 466 & $\begin{array}{l}20.9 \\
(7.5)\end{array}$ & 0.866 & 36 & $\begin{array}{l}18.9 \\
(8.9)\end{array}$ & 0.249 \\
\hline 4-6 people & 870 & $\begin{array}{l}20.7 \\
(7.9)\end{array}$ & & 37 & $\begin{array}{l}17.5 \\
(10.2)\end{array}$ & \\
\hline $6+$ people & 314 & $\begin{array}{l}21.0 \\
(7.7)\end{array}$ & & 26 & $\begin{array}{l}21.3 \\
(6.4)\end{array}$ & \\
\hline \multicolumn{7}{|c|}{ Public Attitude towards mitigation measures } \\
\hline \multicolumn{7}{|c|}{ Practiced self-isolation, $n=1644$} \\
\hline No & 1141 & $\begin{array}{l}22.8 \\
(4.7)\end{array}$ & 0.390 & 83 & $\begin{array}{l}21.9 \\
(5.3)\end{array}$ & 0.871 \\
\hline Yes & 503 & $\begin{array}{l}23.0 \\
(5.1)\end{array}$ & & 50 & $\begin{array}{l}21.8 \\
(5.7)\end{array}$ & \\
\hline \multicolumn{7}{|c|}{$\begin{array}{l}\text { Practiced home quarantine, } \mathrm{n}= \\
1641\end{array}$} \\
\hline No & 989 & $\begin{array}{l}22.8 \\
(4.7)\end{array}$ & 0.814 & 91 & $\begin{array}{l}21.7 \\
(5.3)\end{array}$ & 0.496 \\
\hline
\end{tabular}




\begin{tabular}{|c|c|c|c|c|c|c|}
\hline Variables & $\begin{array}{l}\text { Local } \\
\text { SSA }\end{array}$ & \multicolumn{2}{|c|}{ Scores $P$-value } & $\begin{array}{l}\text { Diaspora } \\
\text { SSA }\end{array}$ & Scores & $\begin{array}{l}P \\
\text { value }\end{array}$ \\
\hline Yes & 652 & \multicolumn{2}{|l|}{$\begin{array}{l}22.9 \\
(4.9)\end{array}$} & 42 & $\begin{array}{l}22.4 \\
(5.9)\end{array}$ & \\
\hline \multicolumn{7}{|c|}{ Feeling about the self-isolation } \\
\hline \multicolumn{7}{|l|}{ Anxious, $n=1463$} \\
\hline No & 592 & $\begin{array}{l}20.8 \\
(7.7)\end{array}$ & 0.865 & 50 & $\begin{array}{l}21.0 \\
(6.8)\end{array}$ & 0.213 \\
\hline Yes & 871 & $\begin{array}{l}20.7 \\
(8.1)\end{array}$ & & 62 & $\begin{array}{l}19.0 \\
(9.4)\end{array}$ & \\
\hline \multicolumn{7}{|l|}{ Bored, $n=1493$} \\
\hline No & 444 & $\begin{array}{l}20.7 \\
(7.9)\end{array}$ & 0.990 & 30 & $\begin{array}{l}19.9 \\
(8.1)\end{array}$ & 0.897 \\
\hline Yes & 1049 & $\begin{array}{l}20.7 \\
(7.9)\end{array}$ & & 87 & $\begin{array}{l}20.1 \\
(8.3)\end{array}$ & \\
\hline \multicolumn{7}{|l|}{ Frustrated, $n=1467$} \\
\hline No & 704 & $\begin{array}{l}20.7 \\
(7.8)\end{array}$ & 0.982 & 63 & $\begin{array}{l}20.5 \\
(8.4)\end{array}$ & 0.657 \\
\hline Yes & 763 & $\begin{array}{l}20.7 \\
(8.2)\end{array}$ & & 56 & $\begin{array}{l}18.4 \\
(8.2)\end{array}$ & \\
\hline \multicolumn{7}{|l|}{ Angry, $n=1418$} \\
\hline No & 1098 & $\begin{array}{l}20.8 \\
(8.0)\end{array}$ & 0.692 & 88 & $\begin{array}{l}22.4 \\
(9.5)\end{array}$ & 0.283 \\
\hline Yes & 320 & $\begin{array}{l}20.6 \\
(7.8)\end{array}$ & & 23 & $\begin{array}{l}19.7 \\
(9.2)\end{array}$ & \\
\hline Knowledge scores ${ }^{\ddagger}$ & 1855 & $7.2(2.2)$ & & 150 & $\begin{array}{l}7.2 \\
(2.5)\end{array}$ & \\
\hline Attitude scores & 1855 & $\begin{array}{l}13.7 \\
(5.2)\end{array}$ & & 150 & $\begin{array}{l}14.0 \\
(5.5)\end{array}$ & \\
\hline
\end{tabular}

\section{Discussion}

This study found a comparable high risk perception score among residents living in SSA and those in the diaspora which were associated with increase in knowledge of COVID-19 and attitude towards the mitigation measures.

Older health care workers had higher risk perception scores compared to younger non health care workers. 
Although having a lower education and not working during the pandemic was associated with a significantly lower risk perception of COVID-19 among local residents, this was nullified after adjusting for other demographic variables.

The finding that older individuals felt at greater risk of COVID-19 was in line with past studies showing that older individuals have significantly higher COVID-19 related severe complications and deaths than young individuals[33]. Public awareness of this information may explain the finding of lower risk perception for contracting the infection among younger respondents in SSA. As highlighted by Dillard et al[34], having a perceived low risk of infection can make young people become less compliant to the public health measures. This can in turn lead to higher COVID-19 infection[34], and ultimately passing the infection to the population more susceptible to COVID-19 related complications, since young people were shown to be more likely to transmit the virus than others[35]. In line with these findings, some countries took stringent steps to limit young population from transmitting COVID-19 infection to older population [36-39] but recorded mixed success[39-41]. Rapid and proactive outreach programs targeted at young people in Australia and Canada might explain why the risk perception was similar between younger and older participants living in the diaspora in this study[42]. Such directed programs and policies should be implemented within the vulnerable groups in our local populations.

Studies have reported a high perceived risk of COVID-19 among African health workers[43-45] but did not compare between health and non-health workers. In a cross-sectional study conducted on 350 Ghanaians during the early stage of the outbreak, there was no difference in risk perception scores between health and non-health care workers[46]. In this study, high risk perception for contracting COVID19 was associated with working in the health sector but this was only significant among those who were living in SSA. Firsthand experience with the virus is often linked to high-risk perception[47], higher knowledge of the disease among health care workers compared to the non-health workers might explain their higher perception of risk for contracting the infection. The lack of proper training on protective measures reported in previous studies by health workers in SSA countries[45] may explain the significant association found among local health care workers but not among those living in the diaspora. Again, the implementation of targeted policies may as well account for the lack of association among respondents living abroad.

In this study, knowledge about COVID-19 and positive attitude towards the mitigation measures were associated with high-risk perception of contracting the disease, both in SSA and the diaspora. Similar findings have been reported in Ethiopia[48] showing that individuals who perceive higher risk are more likely to adopt protective measures, which in turn influences the probability of infection[48, 49]. However, the prevalence of misinformation about COVID-19 among SSA respondents[50] together with the immoderate psychological stress caused by these misinformation about COVID-19 due to the poor knowledge about the disease[31] can also lead to overestimation of negative risks or inaccurate risk judgement $[29,51]$. Hence, accurate information about the pandemic using the trusted media platforms, can help in accurate risk judgement and proper adoption of public health measures to control the spread of infection [31, 52]. 
COVID-19 related morbidity and mortality vary disproportionately based on socio-demographic characteristics, for instance, males and older people have high mortality due to COVID-19 compared to females and young population[53]. Individual's behaviours towards safety measures have been linked to their level of perceived risk of a disease[34]. Adopting public health measures such as the use of nose mask in public areas and frequent hand sanitization, can lead to successful control of air-borne infectious diseases like COVID-19[52]. Therefore, public health strategies for successful control of COVID19 among SSAs may benefit from targeting the sub-population identified in this study.

That is, the unemployed, non-health care workers, the younger population and those with lower levels of education.

This study was limited by several factors, which restricts the generalizability of the present findings. It was an online survey made available only in English language thus restricting respondents without access to the internet where internet penetration remains relatively low and some from French-speaking SSA nations[54]. However, the use of an internet-based methodology was the only reliable means to disseminate information at the time of this study. Notwithstanding these limitations, this study from the SSA region provided insight into the role of place of residence in mitigating the factors that influence risk perception of COVID-19 among SSAs during the pandemic. The study used a robust analysis to control for potential confounders during the analysis in order to reduce the issue of bias.

\section{Conclusions}

In summary, this study explored the factors associated with the risk perception of contracting COVID-19 among SSAs particularly looking at the role of place of residence in peoples' level of risk perception. The findings indicate that health communication and education strategies, which are designed to promote the adoption of preventive behaviours among SSAs, should focus on increasing knowledge about the disease and encouraging positive attitude towards the mitigation measures.

In addition, such programmes will benefit from targeting the unemployed, less educated and non-health care workers for optimum outcome.

These findings can be helpful in policy implications in disaster risk management including infection control of COVID-19 particularly in English speaking countries in the SSA region.

\section{List Of Abbreviations}

COVID-19: coronavirus SARS-CoV2

SSA: Sub-Sahara Africa

Cl: Confidence intervals

EVD: Ebola Virus Disease 
EPPM: Extended parallel process model

WHO: World Health Organization

SPRP: Strategic Preparedness and Response Plans

ANOVA: Analysis of variance

\section{Declarations}

\section{Ethics approval and consent to participate}

The Human Research Ethics Committee of the Cross River State Ministry of Health, Nigeria approved this study (\#: CRSMOH/RP/REC/2020/116). Written informed consent was obtained from all respondents before participation, by asking respondents to voluntarily answer either a 'yes' or 'no' to the question inquiring whether they agreed to participate in the survey. Respondents could only proceed to complete the survey if they answered 'yes' to this question. All protocols are carried out in accordance in accordance with the Helsinki Declaration for Human Research

\section{Consent for publication}

Not applicable

\section{Availability of data and materials}

The datasets used and/or analysed during the current study are available from the corresponding author on reasonable request.

\section{Competing interests}

The authors declare that they have no competing interests

\section{Funding}

No funding was obtained for this study

\section{Authors' contributions}

K.E.A, U.L.O, R.O. conceptualized the study. K.E.A., E.K.A., B.N.E., K.P.M., P.C.G., U.L.O., G.O.O., O.N., R.O., T.I., T.C.G., D.D.C., C.A.M., R.L. and D.B. were involved in data collection and interpretation of the data. K.E.A., D.B. and U.L.O performed the formal analysis of the data. E.K.A., D.B., R.O. and U.L.O. drafted the original manuscript. K.E.A., G.O.O., E.K.A., B.N.E., K.P.M., P.C.G., O.N., R.O., T.I., T.C.G, D.D.C., C.A.M, R.L. and D.B. reviewed and edited the manuscript. K.E.A., T.I., D.D.C., K.P.M. and U.L.O. supervised the project.

\section{Acknowledgement}




\section{References}

1. Paek H-J, Hove T. Risk perceptions and risk characteristics. Oxford research encyclopedia of communication. 2017.

2. Anderson RM, Heesterbeek $H$, Klinkenberg D, Hollingsworth TD. How will country-based mitigation measures influence the course of the COVID-19 epidemic? The Lancet. 2020;395:931-4.

3. Roy D, Tripathy S, Kar SK, Sharma N, Verma SK, Kaushal V. Study of knowledge, attitude, anxiety \& perceived mental healthcare need in Indian population during COVID-19 pandemic. Asian Journal of Psychiatry. 2020:102083.

4. Zito RR. Bounding the "Black Swan" Probability. Mathematical Foundations of System Safety Engineering. Springer; 2020. p. 51-62.

5. McMaster M, Nettleton C, Tom C, Xu B, Cao C, Qiao P. Risk management: rethinking fashion supply chain management for multinational corporations in light of the COVID-19 outbreak. Journal of Risk and Financial Management. 2020;13:173.

6. Roser M, Ritchie H, Ortiz-Ospina E, Hasell J. Coronavirus pandemic (COVID-19). Our world in data. 2020.

7. Pereira M, Paixão E, Trajman A, De Souza RA, Da Natividade MS, Pescarini JM et al. The need for fast-track, high-quality and low-cost studies about the role of the BCG vaccine in the fight against COVID-19. Respiratory research. 2020;21:1-3.

8. Henley J, Connolly K, Jones S. European and US experts question UK's fast-track of COVID vaccine. The Guardian. 20 December.

9. WHO. Coronavirus disease 2019 (COVID-19): situation report, 72. In: Organization WH, editor. Geneva2020.

10. Ferioli M, Cisternino C, Leo V, Pisani L, Palange P, Nava S. Protecting healthcare workers from SARSCoV-2 infection: practical indications. European Respiratory Review. 2020;29.

11. Organization WH. Coronavirus disease 2019 (COVID-19) strategic preparedness and response plan: Accelerating readiness in the Eastern Mediterranean Region: February 2020: World Health Organization. Regional Office for the Eastern Mediterranean2020.

12. Ogolodom MP, Mbaba AN, Alazigha N, Erondu OF, Egbe NO, Golden I et al. Knowledge, Attitudes and Fears of HealthCare Workers towards the Corona Virus Disease (COVID-19) Pandemic in SouthSouth, Nigeria. Health Sci J Sp Iss 1: 002 2020;1:1-10.

13. Di Gennaro F, Pizzol D, Marotta C, Antunes M, Racalbuto V, Veronese $\mathrm{N}$ et al. Coronavirus Diseases (COVID-19) Current Status and Future Perspectives: A Narrative Review. Int J Environ Res Public Health. 2020;17. doi:10.3390/ijerph17082690.

14. Xiao Y, Torok ME. Taking the right measures to control COVID-19. Lancet Infect Dis. 2020;20:523-4. doi:10.1016/s1473-3099(20)30152-3. 
15. Law S, Leung AW, Xu C. Severe acute respiratory syndrome (SARS) and coronavirus disease-2019 (COVID-19): From causes to preventions in Hong Kong. Int $\mathrm{J}$ Infect Dis. 2020;94:156-63. doi:10.1016/j.ijid.2020.03.059.

16. Jahangiry L, Bakhtari F, Sohrabi Z, Reihani P, Samei S, Ponnet K et al. Risk perception related to COVID-19 among the Iranian general population: an application of the extended parallel process model. BMC public health. 2020;20:1-8.

17. McMahan S, Witte K, Meyer Ja. The perception of risk messages regarding electromagnetic fields: extending the extended parallel process model to an unknown risk. Health communication. 1998;10:247-59.

18. Brown P. Studying COVID-19 in light of critical approaches to risk and uncertainty: research pathways, conceptual tools, and some magic from Mary Douglas. Taylor \& Francis; 2020.

19. Barnes SJ. Information management research and practice in the post-COVID-19 world. International Journal of Information Management. 2020;55:102175.

20. Marron JM, Joffe S, Jagsi R, Spence RA, Hlubocky FJ. Ethics and resource scarcity: ASCO recommendations for the oncology community during the COVID-19 pandemic. J Clin Oncol. 2020;38:2201-5.

21. Farrell TW, Francis L, Brown T, Ferrante LE, Widera E, Rhodes R et al. Rationing Limited Health Care Resources in the COVID-19 Era and Beyond: Ethical Considerations Regarding Older Adults. Journal of the American Geriatrics Society. 2020.

22. Tang R, Wu J, Ye M, Liu W. Impact of Economic Development Levels and Disaster Types on the ShortTerm Macroeconomic Consequences of Natural Hazard-Induced Disasters in China. International Journal of Disaster Risk Science. 2019;10:371-85. doi:10.1007/s13753-019-00234-0.

23. De Juan A, Pierskalla J, Schwarz E. Natural disasters, aid distribution, and social conflict-Micro-level evidence from the 2015 earthquake in Nepal. World Development. 2020;126:104715.

24. SAMSHA. Greater Impact: How Disasters Affect People of Low Socioeconomic Status: Substance Abuse and Mental Health Services Administration2017 July.

25. Haeffele S, Storr VH. Government Responses to Crisis. Springer Nature; 2020.

26. Morgado AM. Disasters, individuals, and communities: Can positive psychology contribute to community development after disaster? Community Development. 2020:1-14.

27. Smith VK, Carbone JC, Pope JC, Hallstrom DG, Darden ME. Adjusting to natural disasters. Journal of Risk and Uncertainty. 2006;33:37-54.

28. Quinn T, Bousquet F, Guerbois C, Sougrati E, Tabutaud M. The dynamic relationship between sense of place and risk perception in landscapes of mobility. Ecology and Society. 2018;23.

29. Ferrer RA, Klein WM. Risk perceptions and health behavior. Current opinion in psychology. 2015;5:85-9.

30. Abir T, Kalimullah NA, Osuagwu UL, Yazdani DMN-A, Al Mamun A, Husain T et al. Factors Associated with Perception of Risk and Knowledge of Contracting the Novel COVID-19 among Adults in 
Bangladesh: Analysis of Online Surveys. 2020.

31. Zhong Y, Liu W, Lee T-Y, Zhao H, Ji J. Risk perception, knowledge, information sources and emotional states among COVID-19 patients in Wuhan, China. Nursing Outlook. 2020. doi:https://doi.org/10.1016/j.outlook.2020.08.005.

32. Li Z-H, Zhang X-R, Zhong W-F, Song W-Q, Wang Z-H, Chen Q et al. Knowledge, attitudes, and practices related to Coronavirus disease 2019 during the outbreak among workers in China: A large crosssectional study. PLoS neglected tropical diseases. 2020;14:e0008584.

33. Drefahl S, Wallace M, Mussino E, Aradhya S, Kolk M, Brandén M et al. A population-based cohort study of socio-demographic risk factors for COVID-19 deaths in Sweden. Nature Communications. 2020;11:5097. doi:10.1038/s41467-020-18926-3.

34. Dillard AJ, Ferrer RA, Welch JD. Associations between narrative transportation, risk perception and behaviour intentions following narrative messages about skin cancer. Psychology \& health. 2018;33:573-93.

35. Huang L, Zhang X, Zhang X, Wei Z, Zhang L, Xu J et al. Rapid asymptomatic transmission of COVID19 during the incubation period demonstrating strong infectivity in a cluster of youngsters aged 1623 years outside Wuhan and characteristics of young patients with COVID-19: a prospective contacttracing study. Journal of Infection. 2020.

36. Organization WH. COVID-19 global risk communication and community engagement strategy, December 2020-May 2021: interim guidance, 23 December 2020: World Health Organization2020.

37. Hasmuk K, Sallehuddin H, Tan MP, Cheah WK, Ibrahim R, Chai ST. The long term care COVID-19 situation in Malaysia. International Long-Term Care Policy Network. 2020.

38. Karim W, Haque A, Anis Z, Ulfy MA. The movement control order (mco) for covid-19 crisis and its impact on tourism and hospitality sector in malaysia. International Tourism and Hopitality Yournal. 2020;3:1-7.

39. Cousins S. Experts criticise Australia's aged care failings over COVID-19. The Lancet. 2020;396:1322-3.

40. Hsu AT, Lane N, Sinha SK, Dunning J, Dhuper M, Kahiel Z. Impact of COVID-19 on residents of Canada's long-term care homes-ongoing challenges and policy response. International Long-Term Care Policy Network. 2020;17.

41. Mustaffa N, Lee S-Y, Mohd Nawi SN, Che Rahim MJ, Chee YC, Muhd Besari A et al. COVID-19 in the elderly: A Malaysian perspective. Journal of global health. 2020;10:020370-. doi:10.7189/jogh.10.020370.

42. The impact of the COVID-19 pandemic on jobs and incomes in G20 economies. Saudi Arabia: International Labour Organization2020 19 August.

43. Girma S, Agenagnew L, Beressa G, Tesfaye Y, Alenko A. Risk perception and precautionary health behavior toward COVID-19 among health professionals working in selected public university hospitals in Ethiopia. Plos one. 2020;15:e0241101. 
44. Abdel Wahed WY, Hefzy EM, Ahmed MI, Hamed NS. Assessment of Knowledge, Attitudes, and Perception of Health Care Workers Regarding COVID-19, A Cross-Sectional Study from Egypt. Journal of Community Health. 2020;45:1242-51. doi:10.1007/s10900-020-00882-0.

45. Ekpenyong B, Obinwanne CJ, Ovenseri-Ogbomo G, Ahaiwe K, Lewis OO, Echendu DC et al. Assessment of Knowledge, Practice and Guidelines towards the Novel COVID-19 among Eye Care Practitioners in Nigeria-A Survey-Based Study. International journal of environmental research and public health. 2020;17:5141.

46. Serwaa D, Lamptey E, Appiah AB, Senkyire EK, Ameyaw JK. Knowledge, risk perception and preparedness towards coronavirus disease-2019 (COVID-19) outbreak among Ghanaians: a quick online cross-sectional survey. The Pan African Medical Journal. 2020;35.

47. Dryhurst S, Schneider CR, Kerr J, Freeman ALJ, Recchia G, van der Bles AM et al. Risk perceptions of COVID-19 around the world. Journal of Risk Research. 2020;23:994-1006. doi:10.1080/13669877.2020.1758193.

48. Asefa A, Qanche Q, Hailemariam S, Dhuguma T, Nigussie T. Risk Perception Towards COVID-19 and Its Associated Factors Among Waiters in Selected Towns of Southwest Ethiopia. Risk Management and Healthcare Policy. 2020;13:2601.

49. Herrera-Diestra JL, Meyers LA. Local risk perception enhances epidemic control. PloS one. 2019;14:e0225576.

50. Ovenseri-Ogbomo G, Ishaya T, Osuagwu UL, Abu EK, Nwaeze O, Oloruntoba R et al. Factors associated with the myth about $5 \mathrm{G}$ network during COVID-19 pandemic in sub-Saharan Africa. Journal of Global Health Reports. 2020;4:1-13. doi:doi:10.29392/001c.17606.

51. Galandra C, Cerami C, Santi G, Dodich A, Cappa S, Vecchi T et al. Covid-19 in mind: how job loss and health threatening events modulate risk-taking behaviours in real-life contexts. 2020.

52. Lau JT, Tsui H, Lau M, Yang X. SARS transmission, risk factors, and prevention in Hong Kong. Emerging infectious diseases. 2004;10:587.

53. Williamson EJ, Walker AJ, Bhaskaran K, Bacon S, Bates C, Morton CE et al. Factors associated with COVID-19-related death using OpenSAFELY. Nature. 2020;584:430-6. doi:10.1038/s41586-020-25214.

54. Hjort J, Poulsen J. The arrival of fast internet and employment in Africa. American Economic Review. 2019;109:1032-79.

\section{Figures}




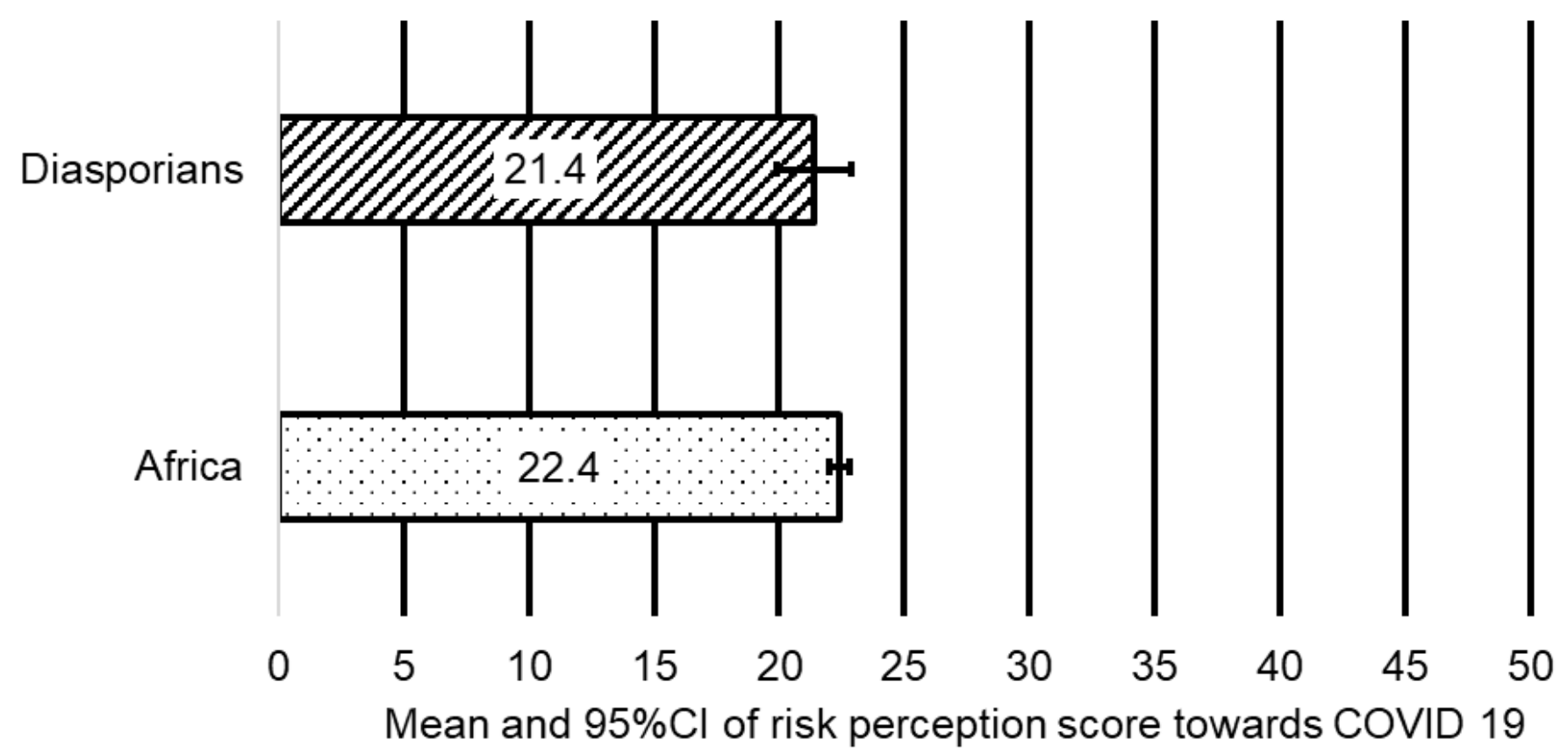

Figure 1

Mean risk perception score towards COVID-19 of respondents living Africa and in the diaspora. Error bars are and $95 \%$ confidence intervals of mean scores 